\title{
A prospective study of factors that lead to invest in mutual funds: A mediating role of investor's perception
}

\author{
Waseem Ul-Hameed ${ }^{a}$, Muhammad Imran ${ }^{\text {b* }}$, Nadeem Maqbool ${ }^{c}$, Sajjad Ahmed ${ }^{\mathrm{c}}$ and \\ Muhammad Azeem ${ }^{\text {d }}$
}

${ }^{a}$ PhD Candidate, School of Economics, Finance \& Banking, Universiti Utara Malaysia, Malaysia

${ }^{b}$ PhD, School of Business Management, Universiti Utara Malaysia, Malaysia

${ }^{c}$ Department of Management sciences, Islamia university of Bahawalpur, Pakistan

${ }^{d}$ School of Technology Management \& Logistics, Universiti Utara Malaysia (UUM), Malaysia

\begin{tabular}{l}
\hline C H R O N I C L E \\
\hline Article history: \\
Received March 3, 2018 \\
Received in revised format June \\
112018 \\
Accepted July 52018 \\
Available online \\
July 62018 \\
\hline Keywords: \\
Mutual funds \\
Investor perception \\
Risk and return \\
Liquidity \\
Tax \\
\end{tabular}

A B S T R A C T

\begin{abstract}
The purpose of the current study is to investigate the various factors influencing on people to invest in mutual funds and examine the mediating role of investor's perception. By using quantitative research approach and cross-sectional research design, 300 questionnaires are distributed among the individual investors and Smart PLS 3 is used to analyze the data. The results reveal that risk and return, liquidity of assets, demographic factors (gender, age, and material status), convenience, reduction in transection cost, tax benefits and transparency were the key factors and maintained significant relationships with investment in mutual funds. Moreover, investor's perception maintains mediating role between all these factors and investment in mutual funds. The study contributes in literature by investigating the various factors, which influence on investors to invest in mutual funds. Moreover, it also contributes by investigating the mediating role of investor's perception.
\end{abstract}

\section{Introduction}

A mutual fund is one of the professionally well-managed investment that generally pools money from a number of investors to purchase various securities. In mutual fund, various factors motivate people to invest in mutual funds. Mutual funds are very important for every business activity (Hameed et al., 2017a,b,c; Hameed et al., 2018). Because risk management is also most important (Hameed et al., 2017) that is why it is important to investigate various factors which influence investors. Thus, any investigation on important factors valued by investors while investing in mutual fund is crucial. Identifying the factors, which change the perception of investors towards mutual funds and motivate them to invest in mutual funds are significant contribution in investment. Mutual funds flow is also important (Parida, \& Wang, 2018) that is the reason to examine various factors influencing on investment.

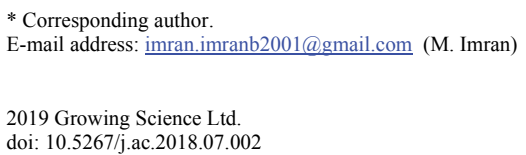


Most mutual fund investors distribute their savings to various well-managed mutual funds schemes, in a hope to beat the market by a mixture of fundamental or technical analysis (Barber et al., 2016). In theory, when measuring an individual fund manager's skill, investors should examine all factors that clarify cross-sectional distinction in fund performance, regardless of whether the factors are priced or unpriced (Grinblatt \& Titman 1989; Pastor \& Stambaugh, 2002).

During the past few decades, several studies have emphasized that fund flows respond to return of fund as mentioned (see, for instance, Ippolito 1992; Chevalier \& Ellison 1997; Sirri \& Tufano, 1998). Furthermore, the relationship between flow of funds and returns tends to be convex; positive returns garner more new flows than those lost to negative returns (Sirri \& Tufano 1998). Brown et al. (1996) and Chevalier and Ellison (1997) argued that mutual funds respond to these implicit incentives by altering the riskiness of their funds to secure a favorable year-end ranking.

However, various other factors affect investment in mutual funds and patrons of funds flow. These factors generally include, risk and returns, liquidity of assets, demographic factors, convenience, reduction in transaction costs, tax benefits and transparency. However, the other politics factors, which affect stock return, are not considered in this study (Maqbool et al., 2018). Therefore, the prime objective of current study is to investigate different factors that affect investment in mutual funds in Pakistan. Moreover, the other objective of study is to investigate the mediating role of investors' perception and its effect to invest in mutual funds.

Thus, this study contributed in literature by investigating the various factors, which influence on investors to invest in mutual funds. Moreover, it also contributed by investigating the mediating role of investors' perception to invest in mutual funds.

\section{Literature Review}

The proliferation of mutual funds has made it a confrontation for investors to decide a right fund for investment. For this purpose, many magazines and newspapers are available to support the investors that they make decisions about their investment. However, the investors have not much expertise to understand the given information and make valuable decisions. There are many websites and financial software packages available as a broadcasting tool to broadcast variables properly and make decisions about asset allocation. However, the majority of investors are not able to make appropriate decision due to lack of information or illiteracy. Another way is to hire the brokerage firm for making the investment decisions according to the investor's preferences, objectives and constraints.

The main objective of selecting the mutual fund process is to decide a fund from a large number of available funds, based on the investor preferences, objectives and constraints. The study states that it is very difficult process to choose a fund that is suitable for the investor's preferences, because many of investors are not expert or having lack of information (Awan \& Arshad, 2012).

This study examines the basic factors that change the attitude of investors towards mutual funds for their investment point of view. The factors are discussed below.

- Risk \& Return

- Liquidity of assets,

- Demographic Factors

- Convenience

- Reduction in transaction costs

- Tax benefits

- Transparency 


\subsection{Risk and Return}

In making investment decision, investors are more careful about higher returns at minimum risk, but it is not possible to get abnormal returns when the markets are efficient. Literature indicates that mostly individual investors do not consider that the mutual funds is a highly risky investment, but when compared with another financial avenue, the market looks more attractive. Those investors, who do not want to take complete risk of capital market volatility, invest in mutual funds to rely on professional management of mutual funds. A survey result exposes a small number of investors think that mutual fund is the most preferred investment and they ranked it as a first position (Walia \& Kiran, 2009). Mutual fund reduces the riskiness of the investments because mutual funds invest in a number of diversified companies across different industries and sectors. Therefore, if one invests in a single company, it tends to be a high risky investment as compared to invest in mutual funds (Rai university, 2012). Another study examines that there is a significant relationship between income level of investors and their perception about investment returns from mutual funds investment. In other words, when an investor's income level is low, he or she will invest in mutual funds for secure returns, but when he or she has great income then the investor moves to the financial institute for getting higher returns against higher risk (Walia \& Kiran, 2009).

Another study based on India shows that a huge number of investors think that mutual fund is a safe medium to invest in share market as compared to direct investment (Vyas, 2012). A study explains that there is a positive relationship between risk and return while investing in mutual funds. It also indicates a significant but positive relation of systematic risk with return (Bansal, \& Kaur, 2016) and this risk and return have significant relationship with perception of an investor.

$\mathbf{H}_{-1}$ : There is a significant positive relationship between risk and return and investment in mutual funds.

\subsection{Demographic Factors}

Investor social factors like gender, age, marital status, educational qualification and level of income provide a perception to investor towards invest in mutual funds.

\section{Gender}

For investment purpose, gender is perceived the most significant factor. Male are the basic winners because they invest in various investments in different sectors. In married people mostly, females invest in mutual funds because of its easiness, liquidity and small investments (Vipparthi \& Margam, 2012).

Age

In investment decision making, age is considered as one of the most important factors because the saving patterns are different according to the age differences (Vipparthi \& Margam, 2012). One study examines whether or not there is a direct relationship between age and investing in mutual funds. A small age people have small money for investment, so they choose to invest in mutual funds but some people who have more amount of money may wish to invest in high risky investment for getting higher return. Since they have a high level of assets, they do not care about loss but as the age increases people tend to become risk averse and they make decision to invest in mutual funds in less risky assets and get a sure return (Ferreira et al., 2012).

A study on teachers shows that as the age of teachers increases, they move to start their investment in mutual funds because of their income increases with age and experience. Due to increase in age, they want to invest in less risky assets for getting secure return, so they try to invest in alternative option of investment like mutual funds (Nandanan \& Thomas, 2013). Additionally, increase in age make the individual risk averse, and develop the leadership qualities with experience, which has significant influence on the decision to invest in mutual funds (Haider et al., 2018). 
Another study states that there is a significant relationship between age and investing in mutual funds. As people' age increase, the investment in mutual funds also increases because people invest their pension funds in mutual funds, which is less risky and they are high liquidity assets (Sharma \& Gounder, 2012). Additionally, increase in age increases the satisfaction level or people become more trained to invest which increases the motivational level (Hussain et al., 2013).

\section{Marital Status}

It is a known fact that married people are more responsible as compared with the unmarried people. They also careful about their investment decision because they may need to fulfill their needs and expenditure in future. Literature also proved that married people are more attracted towards investing in mutual funds as compared with the unmarried people (Vipparthi \& Margam, 2012).

Therefore, it can be described as there is a relationship between marital status and investment in mutual funds. Married people are attracted more towards mutual funds because of its less riskiness and getting safe returns. Thus, unmarried people are less likely to invest in mutual funds as compared with the married people.

H.2: There is a significant positive relationship between demographic factors and investment in mutual funds.

\subsection{Educational Qualification}

Educational qualification is also considered an important factor while investing in mutual funds. Generally, it is perceived that patterns of investment differ according to the level of qualification. Educated people have more abilities and knowledge related to the mutual funds, therefore, they tend to make better decisions. There is a relationship between qualification and investing in mutual funds through the perception level of an investor. As the qualification level is higher, the awareness about investment decisions is also higher (Vipparthi \& Margam, 2012). Hence, increase in educational level increase the investment in mutual funds. However, low educational people are less likely to invest in mutual funds.

H.3: There is a significant positive relationship between higher education and investment in mutual funds.

\subsection{Convenience}

Around 95 million people invest in mutual funds as the largest financial intermediary. Investors who invest in mutual funds may be new comers or experienced. They invest in mutual funds for their convenience in terms of time saving because they invest only money and the manager who managed the mutual fund makes decision about in which securities they need to invest and get higher returns.

Another study indicates that investors invest in mutual funds to save time, reduce paper work and easy investment (Rai university, 2012). The investor perception about investment in mutual funds are any other funds, generally become varies due to various factors such as time, reduce paper work and easy investment.

A study indicates that there is a significant relationship between occupied people and investment in mutual funds. Professional people have a lack of time to get information and they invest in mutual funds because of its easy investment (Vipparthi \& Margam, 2012). Therefore, convenience is one of the most crucial factor, which influence on the investment of an individual.

H.4: There is a significant positive relationship between convenience and investment in mutual funds. 


\subsection{Reduction in Transaction Costs}

Investors who invest in mutual funds get a benefit of reduction in transaction cost. A study suggests that investing in mutual funds is relatively less expensive as compared with investment in other securities. For investing in stocks directly, investor has to pay a transaction fees and broker commission. However, as mutual fund is normally commission free (Rai university, 2012). A study states that investors invest in mutual funds not only because of its risk return performance, but also based on fee structure of the mutual funds. Investors attract to invest in mutual funds due to its less expensiveness (Korpela \& Puttonen, 2006). Thus, low transection cost in mutual funds attract investors to invest more.

H-5: There is a significant positive relationship between reduction in transaction costs and investment in mutual funds.

\subsection{Tax Benefit}

Investors who invest in mutual funds enjoy the tax benefits under the section of $80 \mathrm{~L}$ of the income tax act. Dividends that received from mutual funds investment are tax exempt (Rai university, 2012). Various studies show that investors who invest in mutual funds receive the tax benefits under section $80 \mathrm{C}$ and diversification into multiple sectors. Another study indicates that there is a relationship between tax benefit and investing in mutual funds. People tend to be more attract towards investing in mutual funds because of tax benefit (Huddart \& Narayanan, 2002). Thus, tax benefit in mutual funds attract investors to invest in mutual funds as compared with the other resources. Tax benefit affects positively on the investor's perception, which influence the investment in mutual funds.

H-6: There is a significant positive relationship between tax benefit and investment in mutual funds.

\subsection{Transparency}

The manager who manages the mutual fund portfolio must provide a transparent disclose about the performance of the portfolio every month and this benefits the investors who invest in mutual funds. Investors are informed about their investments where it deployed and, in any situation, if they are not satisfied about their portfolio, they can withdraw their investment at short notice and invest in other portfolio with a better investment performance (Rai university, 2012).

It demonstrates that mutual funds are more liquid as compared to others. A study indicates that there is also a significant benefit while investing in high liquidity mutual funds. Thus, mutual funds are more liquid as well as transparent which affect positively on the investor's perception to invest in mutual funds.

H-7: There is a significant positive relationship between transparency and investment in mutual funds.

Additionally, the in-direct hypotheses are as follows;

$\mathbf{H}_{-8}$ : Investor perception mediates the relationship between risk \& return and investment in mutual funds.

H-9: Investor perception mediates the relationship between demographic factors and investment in mutual funds.

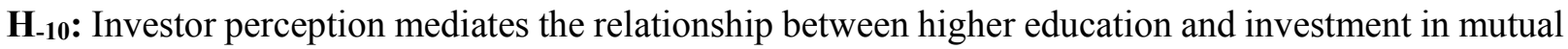
funds.

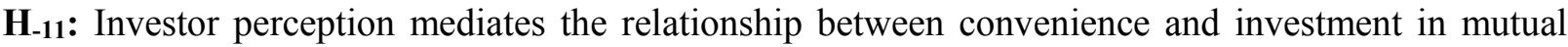
funds.

H-12: Investor perception mediates the relationship between reduction in transaction costs and investment in mutual funds.

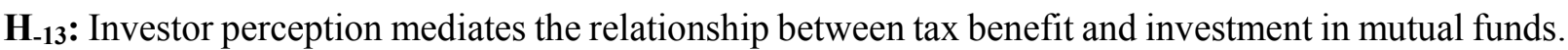


H-14: Investor perception mediates the relationship between transparency and investment in mutual funds.

\section{Identification of Variables}

Dependent Variable

- Investment in Mutual Funds

Independent Variables

- Risk \& Return

- Liquidity of assets

- Demographic Factors

- Convenience

- Reduction in transaction costs

- Tax benefits

- Transparency

Mediating Variable

- Investor Perception
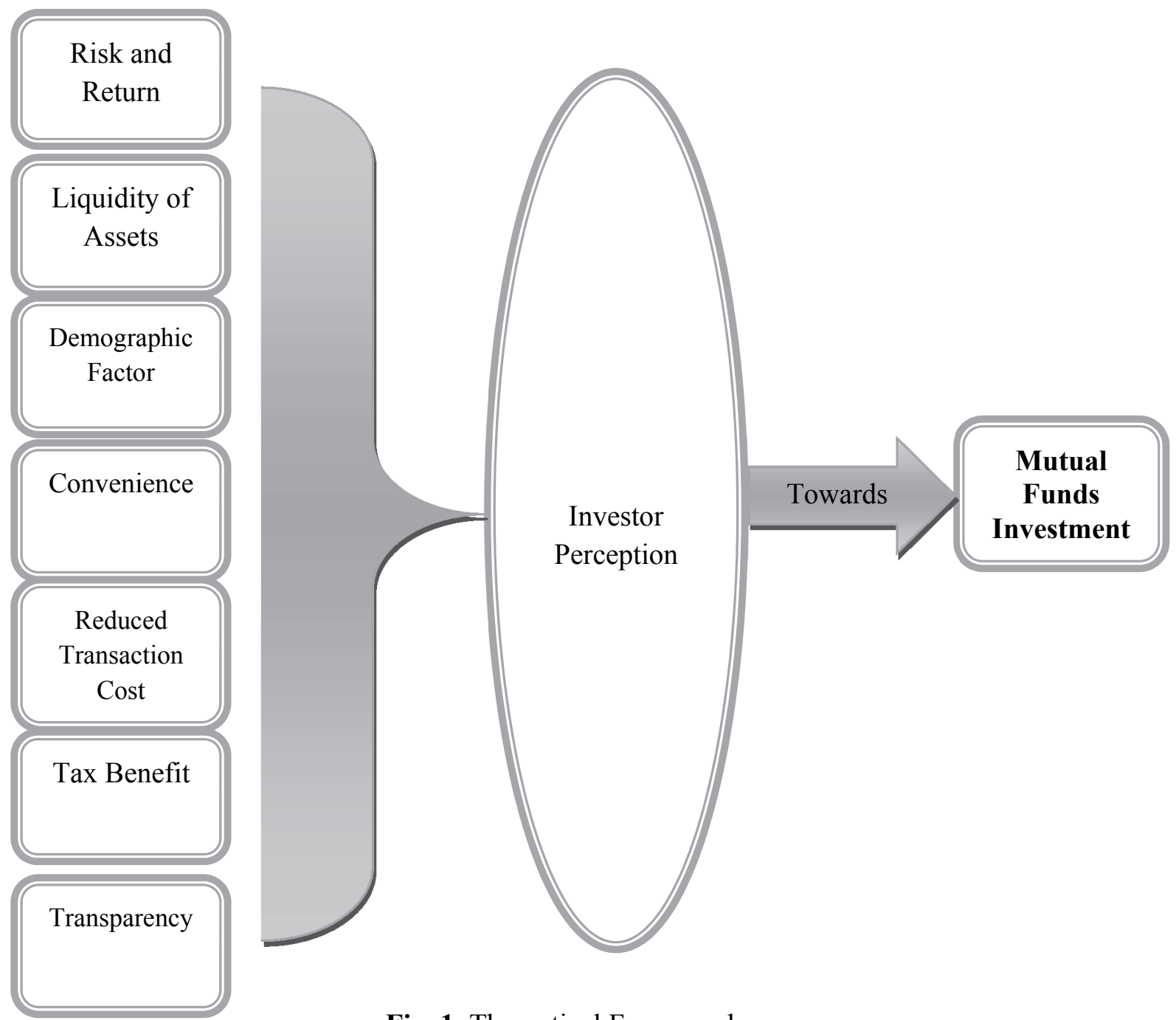

Fig. 1. Theoretical Framework 


\section{Research Method}

As the research method is one of the most crucial step, that is the reason, by considering the objective, problem and nature of the study (Hameed et al., 2017; Imran et al., 2018a,b; Hameed et al., 2018; Imran et al., 2018) quantitative research approach and cross-sectional research design was elected. Data were collected from individual investors from Pakistan by using convenience sampling. Comrey and Lee (1992) provided a sample in a series for inferential statistics. "Sample having less than 50 participants will observed to be a weaker sample; sample of 100 size will be weak; 200 will be adequate; sample of 300 will be considered as good; 500 very good whereas 1000 will be excellent". Thus, in current study, 300 sample size was elected.

Data were collected by using survey technique. The 5-point Likert scale were utilized to collect the data. All the questionnaires were distributed by self-visit to the respondents. Among 300 questionnaires 259 were returned. From 259 questionnaires, 15 were incomplete, therefore, excluded from the study. Thus, 244 questionnaires were used to analyze the data.

SmartPLS 3 was used as a statistical tool to analyze the data. To test the hypotheses, structural equational modeling (SEM) was performed. Both direct and indirect effect were examined to test the hypotheses.

\section{Data Analysis, Results and Findings}

For data analysis, the current study employs the smartPLS 3 . The smartPLS 3 is gaining popularity day by day due to its model parsimony and many studies have used this software for accurate results in context of Pakistan as well (Imran et al., 2017; Imran et al., 2018; Imran et al., 2018). The analysis of the current study was mainly based on two major parts. In the first part, measurement model was assessed to examine the reliability and validity. In the second part, structural model was assessed to test the hypotheses by using structural equational modeling (SEM). In measurement model assessment, factors loading, Cronbach alpha, composite reliability and average variance extracted (AVE) were examined (Hair et al., 2014; Hair et al., 2010; Henseler et al., 2009). Moreover, discriminant validity was examined to assess the external consistency. According to Hair et al. (2014), factor loading should be more than 0.5. Fornell and Larcker (1981) suggested that to achieve the convergent validity, the AVE should be more than or equal to 0.5 . Moreover, the reliability should also be more than or equal to 0.7. Fig. 2 shows the measurement model assessment and Table 1 shows the results of measurement model assessment. It indicates that all the values are above the minimum threshold level. Additionally, Table 2 shows the discriminant validity.

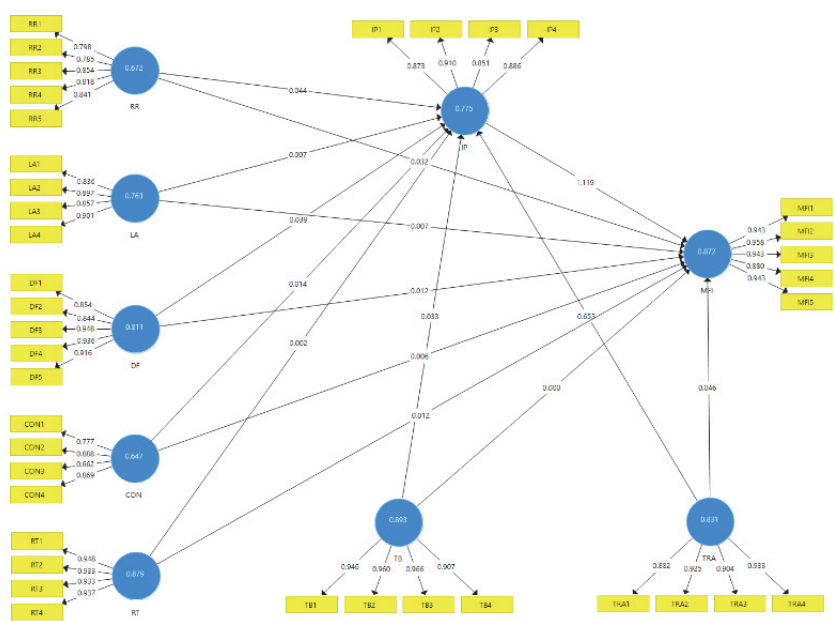

Fig. 2. Measurement Model Assessment 
Table 1

Factor Loading, Cronbach Alpha, Composite Reliability, AVE.

\begin{tabular}{|c|c|c|c|c|c|}
\hline Construct & Indicators & Loadings & Cronbach Alpha & $\begin{array}{l}\text { Composite } \\
\text { Reliability }\end{array}$ & $A V E$ \\
\hline Risk \& Return (RR) & $\begin{array}{l}\text { RR1 } \\
\text { RR2 } \\
\text { RR3 } \\
\text { RR4 } \\
\text { RR5 }\end{array}$ & $\begin{array}{l}.798 \\
.785 \\
.854 \\
.818 \\
.841\end{array}$ & .878 & .911 & .672 \\
\hline Liquidity of Assets (LA) & $\begin{array}{l}\text { LL1 } \\
\text { LL2 } \\
\text { LL3 } \\
\text { LL4 }\end{array}$ & $\begin{array}{l}.836 \\
.897 \\
.857 \\
.801\end{array}$ & .896 & .928 & .763 \\
\hline Demographic Factors (DF) & $\begin{array}{l}\text { DF1 } \\
\text { DF2 } \\
\text { DF3 } \\
\text { DF4 } \\
\text { DF4 }\end{array}$ & $\begin{array}{l}.854 \\
.844 \\
.948 \\
.936 \\
.916\end{array}$ & .941 & .955 & .811 \\
\hline Convenience (CON) & $\begin{array}{l}\text { CON1 } \\
\text { CON2 } \\
\text { CON3 } \\
\text { CON4 }\end{array}$ & $\begin{array}{l}.777 \\
.888 \\
.662 \\
.869\end{array}$ & .816 & .878 & .647 \\
\hline $\begin{array}{l}\text { Reduced Transection Cost } \\
(R T)\end{array}$ & $\begin{array}{l}\text { LT1 } \\
\text { LT2 } \\
\text { LT3 } \\
\text { LT4 }\end{array}$ & $\begin{array}{l}.948 \\
.933 \\
.933 \\
.937\end{array}$ & .954 & .967 & .879 \\
\hline Tax Benefit (TB) & $\begin{array}{l}\text { TB1 } \\
\text { TB2 } \\
\text { TB3 } \\
\text { TB4 }\end{array}$ & $\begin{array}{l}.946 \\
.960 \\
.966 \\
.907\end{array}$ & .960 & .971 & .893 \\
\hline Transparency (TRA) & $\begin{array}{l}\text { TRA1 } \\
\text { TRA2 } \\
\text { TRA3 } \\
\text { TRA4 }\end{array}$ & $\begin{array}{l}.882 \\
.925 \\
.904 \\
.933\end{array}$ & .932 & .951 & .831 \\
\hline Investor Perception (IP) & $\begin{array}{l}\text { IP1 } \\
\text { IP2 } \\
\text { IP3 } \\
\text { IP4 }\end{array}$ & $\begin{array}{l}.873 \\
.910 \\
.851 \\
.886\end{array}$ & .903 & .932 & .775 \\
\hline $\begin{array}{l}\text { Mutual Fund Investment } \\
\text { (MFI) }\end{array}$ & $\begin{array}{l}\text { MFI1 } \\
\text { MFI2 } \\
\text { MFI3 } \\
\text { MFI4 } \\
\text { MFI5 }\end{array}$ & $\begin{array}{l}.943 \\
.958 \\
.943 \\
.880 \\
.942\end{array}$ & .963 & .971 & .872 \\
\hline
\end{tabular}

Table 2

Discriminant Validity

\begin{tabular}{llllllllll}
\hline & CON & DF & IP & LA & MFI & RR & RT & TB & TRA \\
\hline CON & $\mathbf{0 . 8 6 3}$ & & & & & & & & \\
DF & 0.804 & $\mathbf{0 . 9 0 1}$ & & & & & & & \\
IP & 0.777 & 0.812 & $\mathbf{0 . 8 8 4}$ & & & & & & \\
LA & 0.785 & 0.897 & 0.781 & $\mathbf{0 . 8 7 3}$ & & & & & \\
MFI & 0.728 & 0.750 & 0.916 & 0.729 & $\mathbf{0 . 9 3 4}$ & & & & \\
RR & 0.797 & 0.865 & 0.729 & 0.808 & 0.694 & $\mathbf{0 . 8 2 0}$ & & & \\
RT & 0.806 & 0.776 & 0.694 & 0.753 & 0.623 & 0.760 & $\mathbf{0 . 9 3 8}$ & & \\
TB & 0.835 & 0.828 & 0.815 & 0.736 & 0.747 & 0.780 & 0.707 & $\mathbf{0 . 9 4 5}$ & \\
TRA & 0.728 & 0.761 & 0.880 & 0.758 & 0.779 & 0.754 & 0.700 & 0.789 & $\mathbf{0 . 9 1 1}$ \\
\hline
\end{tabular}

After the assessment of measurement model, structural model assessment was performed. In this part of analysis, PLS bootstrapping was performed to examine the direct and indirect effects. Total variance 
explained was examined through R-Squared $\left(\mathrm{R}^{2}\right)$. Moreover, the effect size $\left(\mathrm{f}^{2}\right)$ of each exogenous variable was investigated. Finally, the quality of model was assessed through predictive relevance $\left(\mathrm{Q}^{2}\right)$.

To test the hypotheses, minimum threshold level of t-value was 1.96. Table 3 shows the direct effect of independent variables on dependent variable without mediation. It is clear that all the relationships have t-value more than 1.96 and positive $\beta$-value. Thus, all the direct variables have significant relationships with dependent variable. Therefore, H-1, H-2, H-3, H-4, H-5, H-6 and H-7 are accepted.

It demonstrates that risk and return, liquidity of assets, demographic factors (gender, age, and material status), convenience, reduction in transection cost, tax benefits and transparency had significant and positive relationships with mutual funds investment. Male individuals increase in age and married individuals are more likely to invest in mutual funds. Low tax, transparency, convenience, definite return and low risk increase the investment in mutual funds.

Table 3

Direct Effect

\begin{tabular}{lcccc}
\hline Relationship & Original Sample (O) & $\begin{array}{c}\text { Standard Deviation } \\
(\text { STDEV) }\end{array}$ & $\begin{array}{c}\text { T Statistics } \\
(\mid \mathrm{O} / \text { STDEV })\end{array}$ & $\begin{array}{c}\text { P } \\
\text { Values }\end{array}$ \\
\hline $\mathrm{CON} \rightarrow$ MFI & 0.190 & 0.050 & 3.780 & 0.001 \\
$\mathrm{DF} \rightarrow$ MFI & 0.116 & 0.029 & 3.980 & 0.000 \\
$\mathrm{LA} \rightarrow$ MFI & 0.266 & 0.035 & 7.591 & 0.000 \\
$\mathrm{RR} \rightarrow$ MFI & 0.151 & 0.026 & 5.793 & 0.000 \\
$\mathrm{RT} \rightarrow$ MFI & 0.114 & 0.014 & 8.090 & 0.000 \\
$\mathrm{~TB} \rightarrow$ MFI & 0.154 & 0.078 & 1.971 & 0.049 \\
$\mathrm{TRA} \rightarrow$ MFI & 0.414 & 0.166 & 2.492 & 0.013 \\
\hline
\end{tabular}

Table 4 shows the in-direct effect (mediation). In this step, all the hypotheses related to mediation were tested. While mediation test, instructions of Preacher and Hayes (2004), Preacher and Hayes (2008) was followed. The results of the analysis show that all hypotheses maintained t-value more than 1.96, which validate the mediation effect. Thus, H-8, H-9, H-10, H-11, H-12, H-13 and H-14 are accepted.

It demonstrates that investor perception is one of the mediating variables between all direct factors (risk and return, liquidity of assets, demographic factors, convenience, reduction in transection cost, tax benefits and transparency) and mutual funds investment. However, the $\beta$-value is positive for all mediation hypotheses. It means that investors' perception enhance the positive effect of all direct factors on mutual funds investment.

Table 4

In-Direct Effect (Mediation)

\begin{tabular}{lcccc}
\hline Relationship & $\begin{array}{c}\text { Original Sample } \\
(\mathrm{O})\end{array}$ & $\begin{array}{c}\text { Standard Deviation } \\
(\text { STDEV })\end{array}$ & $\begin{array}{c}\text { T Statistics } \\
(\mid \mathrm{O} / \text { STDEV } \mid)\end{array}$ & $\begin{array}{c}\mathrm{P} \\
\text { Values }\end{array}$ \\
\hline $\mathrm{CON} \rightarrow \mathrm{IP} \rightarrow$ MFI & 0.106 & 0.106 & 0.997 & 0.319 \\
$\mathrm{DF} \rightarrow \mathrm{IP} \rightarrow$ MFI & 0.218 & 0.111 & 1.962 & 0.050 \\
$\mathrm{LA} \rightarrow \mathrm{IP} \rightarrow$ MFI & 0.175 & 0.089 & 1.964 & 0.049 \\
$\mathrm{RR} \rightarrow \mathrm{IP} \rightarrow$ MFI & 0.357 & 0.090 & 3.963 & 0.000 \\
$\mathrm{RT} \rightarrow \mathrm{IP} \rightarrow$ MFI & 0.280 & 0.071 & 3.941 & 0.000 \\
$\mathrm{~TB} \rightarrow \mathrm{IP} \rightarrow$ MFI & 0.192 & 0.045 & 4.231 & 0.000 \\
$\mathrm{TRA} \rightarrow \mathrm{IP} \rightarrow$ MFI & 0.541 & 0.121 & 4.487 & 0.000 \\
\hline
\end{tabular}

Table 5 shows value R-Squared $\left(\mathrm{R}^{2}\right)$. It indicates that all the exogenous variables are expected to explain $84.5 \%$ variance in endogenous variable. According to Chin (1998) this $\mathrm{R}^{2}$ value is substantial. On the other hand, Table 6 shows the effect size $\left(\mathrm{f}^{2}\right)$ of each variable. Risk and return, and tax benefit had moderate effect size $\left(\mathrm{f}^{2}\right)$ and investor perception had strong effect size $\left(\mathrm{f}^{2}\right)$. However, all other 
variables have small effect size $\left(\mathrm{f}^{2}\right)$. As according to Cohen (1988), 0.02 is small, 0.15 is moderate and 0.35 is strong effect size $\left(\mathrm{f}^{2}\right)$.

Table 5

The results of R-Squared $\left(\mathrm{R}^{2}\right)$

\begin{tabular}{lc}
\hline Latent variable & Variance explained $\left(\mathrm{R}^{2}\right)$ \\
\hline Mutual Fund Investment (MFI) & $84.5 \%$ \\
\hline
\end{tabular}

Table 6

Effect size $\left(\mathrm{f}^{2}\right)$

\begin{tabular}{lcc}
\hline R-Squared & f-squared & $\mathrm{f}^{2}$ \\
\hline Risk \& Return (RR) & 0.161 & Moderate \\
Liquidity of Assets (LA) & 0.058 & Small \\
Demographic Factors (DF) & 0.087 & Small \\
Convenience (CON) & 0.033 & Small \\
Reduced Transection Cost (RT) & 0.027 & Small \\
Tax Benefit (TB) & 0.186 & Moderate \\
Transparency (TRA) & 0.269 & Small \\
Investor Perception (IP) & 0.673 & Strong \\
\hline
\end{tabular}

Finally, the predictive relevance $\left(\mathrm{Q}^{2}\right)$ is given in Table 7 , which shows the quality of the model. Predictive relevance $\left(\mathrm{Q}^{2}\right)$ is the supplementary assessment of goodness-of-fit (Duarte \& Raposo, 2010). It should be more than zero (Chin, 1998).

Table 7

Predictive relevance $\left(\mathrm{Q}^{2}\right)$

\begin{tabular}{lccc}
\hline & SSO & SSE & $\mathrm{Q}^{2}=(1-\mathrm{SSE} / \mathrm{SSO})$ \\
\hline Mutual Fund Investment (MFI) & 360.000 & 112.934 & 0.686 \\
Investor Perception (IP) & 288.000 & 114.924 & 0.601 \\
\hline
\end{tabular}

\section{Conclusion}

This study has been conducted on various factors influencing on investors' investment decisions in mutual funds. The results of the survey have revealed that risk, return and liquidity of assets enhanced the investment in mutual funds. Investors who participated in our survey believed that there is a low risk in returns and liquidity in mutual funds. Demographic factors such as gender, age and material status maintained significant effects on investment decisions in mutual funds. The male individuals were more likely to invest in mutual funds as compared with female individual investors. Increase in age increased the intention to invest in mutual funds. Moreover, married people were also more likely to invest in mutual funds compared with other investment plans. Moreover, investment in mutual funds has appeared to be more convenient that is why more people were interested in investing in these types of funds. Additionally, other factors such as low transection cost, low tax rates and transparency in mutual funds have seemed to attract investors to invest in mutual funds.

\section{References}

Awan, H. M., \& Arshad, S. (2012). Factors valued by investors while investing in mutual fundsa behavioral context. Interdisciplinary Journal of Contemporary Research in Business, 4(1), p503.

Bansal, A., \& Kaur, A. (2016). A risk and return analysis of selected unit linked insurance plans of selected public and private sector insurance companies. International Journal of Economics and Business Research, 11(1), 83-99. 
Barber, B. M., Huang, X., \& Odean, T. (2016). Which factors matter to investors? Evidence from mutual fund flows. The Review of Financial Studies, 29(10), 2600-2642.

Brown, K. C., Harlow, W. V., \& Starks, L. T. (1996). Of tournaments and temptations: An analysis of managerial incentives in the mutual fund industry. The Journal of Finance, 51(1), 85-110.

Chevalier, J., \& Ellison, G. (1997). Risk taking by mutual funds as a response to incentives. Journal of Political Economy, 105(6), 1167-1200.

Chin, W. W. (1998). The partial least squares approach to structural equation modeling. Modern Methods for Business Research, 295(2), 295-336.

Cohen, J. (1988). Statistical power analysis for the behavioral sciences . Hilsdale. NJ: Lawrence Earlbaum Associates, 2.

Comrey, A. L., \& Lee, H. B. (1992). A first course in factor analysis, 2nd ed. Hillside, NJ: Erlbaum

Duarte, P. A. O., \& Raposo, M. L. B. (2010). A PLS model to study brand preference: An application to the mobile phone market. In Handbook of partial least squares (pp. 449-485). Springer, Berlin, Heidelberg.

Ferreira, M. A., Keswani, A., Miguel, A. F., \& Ramos, S. B. (2012). The flow-performance relationship around the world. Journal of Banking \& Finance, 36(6), 1759-1780.

Fornell, C., \& Larcker, D. F. (1981). Evaluating structural equation models with unobservable variables and measurement error. Journal of Marketing Research, 18(1), 39-50.

Grinblatt, M., \& Titman, S. (1989). Portfolio performance evaluation: Old issues and new insights. The Review of Financial Studies, 2(3), 393-421.

Haider, S., Nisar, Q. A., Baig, F., \& Azeem, M. (2018). Dark side of leadership: Employees' job stress $\&$ deviant behaviors in pharmaceutical industry. International Journal of Pharmaceutical Research $\&$ Allied Sciences, 7(2).

Hair Jr, J., Sarstedt, M., Hopkins, L., \& G. Kuppelwieser, V. (2014). Partial least squares structural equation modeling (PLS-SEM) An emerging tool in business research. European Business Review, 26(2), 106-121.

Hair, J.F., Black, W.C., Babin, B.J., Anderson, R.E., \& Tatham, R.L. (2010). Multivariate Data Analysis. Prentice Hall.

Hameed, W. U., Azeem, M., Ali, M., Nadeem, S., \& Amjad, T. (2017a). The role of distribution channels and educational level towards insurance awareness among the general public. International Journal of Supply Chain Management, 6(4), 308-318.

Hameed, W. U., Hashmi, F., Ali, M., \& Arif, M. U. H. A. M. M. A. D. (2017b). Enterprise Risk Management (ERM) System: Implementation problem and role of audit effectiveness in Malaysian firms. Asian Journal of Multidisciplinary Studies, 5(11).

Hameed, W. U., Hussin, T., Azeem, M., Arif, M., \& Basheer, M. F. (2017c). Combination of microcredit and micro-training with mediating role of formal education: A micro-enterprise success formula. Journal of Business and Social Review in Emerging Economies, 3(2), 285-291.

Hameed, U.H., Shabbir, M.S., Raza, A., \& Salman, A., (2019). Remedies of low performance among Pakistani e-logistic companies: The role of firm's IT capability and information communication technology (ICT). Uncertain Supply Chain Management, 7.

Hameed, W. U., Nadeem, S., Azeem, M., Aljumah, A. I., \& Adeyemi, R. A. (2018). Determinants of E-Logistic Customer Satisfaction: A Mediating Role of Information and Communication Technology (ICT). International Journal of Supply Chain Management, 7(1), 105-111.

Hameed, W.U.L., Mohammad H.B., \& Shahar, H. K. (2018). Pursuing Goal of Self-Sustainability but Leads towards More Instability: Challenges and Way Forward of Self-Help Groups (SHGs). International Journal of Business and Tehnopreneurship, 8(1), 67-76.

Henseler, J., Ringle, C. M., \& Sinkovics, R. R. (2009). The use of partial least squares path modeling in international marketing. In New challenges to international marketing (pp. 277-319). Emerald Group Publishing Limited.

Huddart, S., \& Narayanan, V. G. (2002). An empirical examination of tax factors and mutual funds' stock sales decisions. Review of Accounting Studies, 7(2-3), 319-341. 
Hussain, S., Rizwan, M., Nawaz, M. S., \& ul Hameed, W. (2013). Impact of effective training program, job satisfaction and reward management system on the employee motivation with mediating role of employee commitment. Journal of Public Administration and Governance, 3(3), 278-293.

Imran, M., Aziz, A.B., Hamid, S. N. B. A., \& Hameed, W. U. (2019). The contributing factors towards e-logistic customer satisfaction: a mediating role of information Technology. Uncertain Supply Chain Management, 7(1).

Imran, M., Aziz, A., \& Hamid, S. (2017). Determinants of SME export performance. International Journal of Data and Network Science, 1(2), 39-58.

Imran, M., Aziz, A., Hamid, S., Shabbir, M., Salman, R., \& Jian, Z. (2018a). The mediating role of total quality management between entrepreneurial orientation and SMEs export performance. Management Science Letters, 8(6), 519-532.

Imran, M., Hamid, S., \& Aziz, A. (2018b). The influence of TQM on export performance of SMEs: Empirical evidence from manufacturing sector in Pakistan using PLS-SEM. Management Science Letters, 8(5), 483-496.

Ippolito, R. A. (1992). Consumer reaction to measures of poor quality: Evidence from the mutual fund industry. The Journal of Law and Economics, 35(1), 45-70.

Korpela, M., \& Puttonen, V. (2006). Mutual fund expenses: Evidence on the effect of distribution channels. Journal of Financial Services Marketing, 11(1), 17-29.

Maqbool, N., Hameed, W.U.L. \& Habib, M. U. (2018). Impact of political influences on stock returns. International Journal of Multidisciplinary Scientific Publication (IJMSP), 1(1).

Nandanan, P., \& Thomas, J. (2013). A study of mutual funds as an investment option of personal finance of college teachers at Bangalore. DRIEMS Business Review, 1(1), 34.

Parida, S., \& Wang, Z. (2018). Financial crisis and corporate social responsible mutual fund flows. International Journal of Financial Studies, 6(1), 8.

Pastor, L., \& R. F. Stambaugh (2002). Investing in equity mutual funds. Journal of Financial Economics, 63, 351-80.

Preacher, K. J., \& Hayes, A. F. (2008). Asymptotic and resampling strategies for assessing and comparing indirect effects in multiple mediator models. Behavior research methods, 40(3), 879891.

Preacher, K. J., \& Hayes, A. F. (2004). SPSS and SAS procedures for estimating indirect effects in simple mediation models. Behavior Research Methods, Instruments, \& Computers, 36(4), 717-731.

Rai University (2012). A report on mutual funds. Rai University, 2012.

Sharma, P., \& Gounder, N. (2012). Profitability determinants of deposit institutions in small, underdeveloped financial systems: the case of Fiji. Griffith Business School Discussion Papers Finance, 6.

Sirri, E. R., \& Tufano, P. (1998). Costly search and mutual fund flows. The Journal of Finance, 53(5), 1589-1622.

Vipparthi, M., \& Margam, A. (2012). Perceptions of investors on mutual funds-a comparative study on public and private sector mutual funds. Tecnia Journal of Management Studies, 6.

Vyas, R. (2012). Mutual fund investor's behaviour and perception in Indore city. Researchers World, 3(3), 67.

Walia, N., \& Kiran, R. (2009). An analysis of investor's risk perception towards mutual funds services. International Journal of business and Management, 4(5), 106.

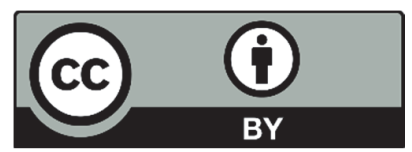

(C) 2019 by the authors; licensee Growing Science, Canada. This is an open access article distributed under the terms and conditions of the Creative Commons Attribution (CC-BY) license (http://creativecommons.org/licenses/by/4.0/). 